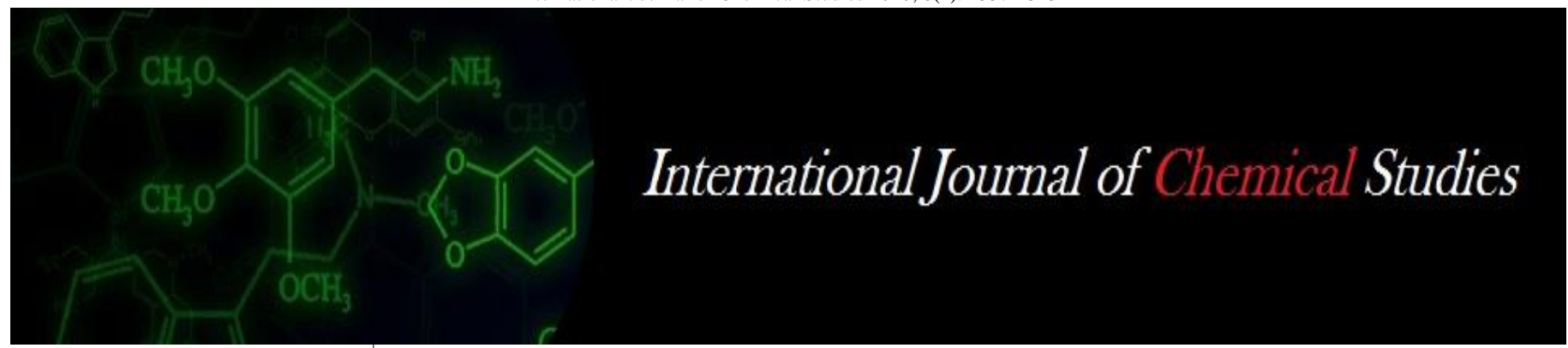

P-ISSN: 2349-8528

E-ISSN: 2321-4902

www.chemijournal.com

IJCS 2020; 8(4): 1337-1343

(C) 2020 IJCS

Received: 10-05-2020

Accepted: 14-06-2020

Bhushan Pagar

Department of Soil Science and

Agricultural Chemistry,

Vasantrao Naik Marathwada

Krishi Vidyapeeth, Parbhani,

Maharashtra, India

Syed Ismail

Department of Soil Science and Agricultural Chemistry,

Vasantrao Naik Marathwada

Krishi Vidyapeeth, Parbhani,

Maharashtra, India
Corresponding Author:

Bhushan Pagar

Department of Soil Science and

Agricultural Chemistry,

Vasantrao Naik Marathwada

Krishi Vidyapeeth, Parbhani,

Maharashtra, India

\section{Effect of zinc mobilizing microbial cultures and zinc levels enhancing yield and enzymatic activity in soybean grown on Vertisol}

\author{
Bhushan Pagar and Syed Ismail
}

DOI: https://doi.org/10.22271/chemi.2020.v8.i41.9786

\begin{abstract}
Field experiment was conducted during Kharif season of 2017 at Research Farm, Department of Soil Science and Agricultural Chemistry at Vasantrao Naik Marathwada Krishi Vidyapeeth, Parbhani on zinc deficient Vertisol to study the zinc solubilization potential of different microorganisms in soybean crop. The experiment consist of sixteen treatment in which four laboratory pre-evaluated zinc solubilizing microbial cultures (Control, Pseudomona strita, Bacillus megaterium, and Trichoderma viride) and four graded doses of $\mathrm{ZnSo} 4\left(0,10,20,30, \mathrm{~kg} \mathrm{ha}^{-1}\right)$ were used in the factorial randomized block design. The results emerged out indicated significant increase in yield and enzymatic activity of soybean grown soil was improved in the plots treated with pseudomon strita along with $30 \mathrm{~kg} \mathrm{ZnSo} 4 \mathrm{ha}^{-1}$ and was found as the best combination in overall improvement of yield and enzymatic activity of soybean grown soil.
\end{abstract}

Keywords: Mobilizing, microbial, cultures, enzymatic activity, Vertisol

\section{Introduction}

Major soybean growing states in India are Madhya Pradesh, Maharashtra, Gujarat, Rajasthan, Karnataka and Andhra Pradesh. Maharashtra ranks $2^{\text {nd }}$ in terms of production of soybean after Madhya Pradesh. In India area, production and productivity of soybean during 2017 is 101.5 lakh ha, 91.4 lakh million tonnes and $900 \mathrm{~kg} \mathrm{ha}^{-1}$, respectively, in Maharashtra area, production and productivity of soybean during 2017 is 34.4 lakh ha, 31.8 lakh million tonnes and $925 \mathrm{~kg} \mathrm{ha}^{-1}$, respectively. (Anonymous, 2017) ${ }^{[1]}$. The area under soybean cultivation is increasing due to some reason such as soybean is short duration crop (90-110 days), good market price with its higher productivity compared to other pulses. It can be processed easily for different products viz., soy cheese, soy milk, soy protein, soy yogurt, soybean oil, soy nut etc. Soybean is also used for making the soy ink, soy paint and soy molasses. It can give a boost to the food-processing industry in rural areas of India. Soybean is miracle golden bean of $21^{\text {st }}$ century which possesses potential to revolutionized Indian economy by correcting the health of human being and soil.

The biochemical properties of soil have often been proposed as early and sensitive indicators of soil ecosystem health. Activities of soil enzymes indicate the direction and strength of all kinds of biochemical processes in soil and act as key biological indicator of soil. Soil enzymes play an essential role in energy transfer environmental quality, organic matter decomposition, nutrient cycling and crop productivity. (Usha Mina et al., 2011) ${ }^{[2]}$. A bacterial based approach was devised to solve the micro nutrient deficiency problem. The basic principle behind this approach is decreasing the $\mathrm{pH}$ and making zinc soluble and as a consequence the available zinc will get increased in the soil system. The term called zinc solubilizing bacteria was coined for those bacteria that are capable of solubilizing the insoluble zinc compounds or minerals in agar plate as well as in soil. (Sarathamble et al., 2010) ${ }^{[3]}$.

\section{Material and Methods}

The present investigation was carried at Research Farm, Department of Soil Science and Agricultural Chemistry at Vasantrao Naik Marathwada Krishi Vidyapeeth, Parbhani on Vertisol during 2017-18. 
The initial soil pH was 8.20, EC-0.22 $\mathrm{dSm}^{-1}$, Organic Carbon$4.43 \mathrm{~g} \mathrm{~kg}^{-1}$, Calcium carbonate $-4.05 \%$, available nitrogen$145 \mathrm{~kg} \mathrm{ha}^{-1}$, Phosphorus -15.23, Potassium- $556 \mathrm{~kg} \mathrm{ha}^{-1}$ and Sulphur-9.38 mg kg-1 The initial micronutrient status was DTPA Copper-2.38, Mangnease-7.34, Zinc-0.58 and Ferrous $-3.15 \mathrm{mg} \mathrm{kg}^{-1}$. The soil was clayey in texture, moderately alkaline in reaction, medium in available nitrogen, phosphorus and sufficient in available potassium and low in sulphur and iron.

The field experiment was carried out on soybean crop (Variety MAU-162) in kharif season during year 2017-18. After completion of preparatory tillage operations, the experiment was laid out in factorial randomized block design comprising (16) treatments and replicated (3) times.

\section{The experiment Consist of two factors}

Factor-1- Zinc levels Factor-2- Zinc mobilizing cultures

1. Zno- $0 \mathrm{~kg} \mathrm{ZnSo} 4 \mathrm{ha}^{-1} 1$. SO- Control

2. Zn1- $10 \mathrm{~kg} \mathrm{ZnSo} 4 \mathrm{ha}^{-1}$ 2. S1- Pseudomona strita

3. Zn2- $20 \mathrm{~kg} \mathrm{ZnSo} 4 \mathrm{ha}^{-1} 3$. S2- Bacillus megaterium

4. Zn3- $30 \mathrm{~kg} \mathrm{ZnSo} 4 \mathrm{ha}^{-1}$ 4. S3- Trichoderma Viride

Seed treatment was done immediate before sowing with liquid zinc mobilizing cultures @ $100 \mathrm{ml} 10 \mathrm{~kg}^{-1}$ seed. The crop was raised following recommended agronomic practices. The recommended dose of chemical fertilizer applied @ 30:60:30 NPK kg ha-1.

The soil sample was collected after harvest of soybean for analysis of chemical properties and available nutrients status as per standard procedures.

\section{Results and Discussion \\ Effect of zinc mobilizing cultures and zinc levels on seed and straw yield of Soybean}

Data given in Table 1 reveal significant increase of seed and straw yield due to addition of zinc solubilizing microorganisms. Zinc solubilizers influenced the seed yield which ranged between 1941 to $2345 \mathrm{~kg} \mathrm{ha}^{-1}$ and straw yield 2731 to $2866 \mathrm{~kg} \mathrm{ha}^{-1}$ showing significantly higher seed and straw yield in Pseudomona strita treated plots follows by Bacillus megaterium and Trichoderma viride. Whereas, significantly lower seed and straw yield per plot were noted in uninoculated control. Similarly graded levels of zinc in the form of zinc sulphate also increased the seed and straw yield with each incremental dose up to $30 \mathrm{~kg} \mathrm{ZnSO}_{4} \mathrm{~kg} \mathrm{ha}^{-1}$. The seed yield as influenced by $\mathrm{Zn}$ application ranged from 1741 to 2426 and straw yield 2591 to $2942 \mathrm{~kg} \mathrm{ha}^{-1}$.

Interaction effect of zinc mobilizing cultures and zinc levels on seed and straw yield of soybean is given in Table 1a. Synergistic effect of both factor was recorded on each other showing significantly highest seed yield in Pseudomona striata X $\mathrm{ZnSO}_{4} 30 \mathrm{~kg} \mathrm{ha}^{-1}\left(2426 \mathrm{~kg} \mathrm{ha}^{-1}\right)$ and straw yield $\left(2786 \mathrm{~kg} \mathrm{ha}^{-1}\right)$ it was found a $\mathrm{t}$ par with Bacillus megaterium $\mathrm{X} \mathrm{ZnSO} 430 \mathrm{~kg} \mathrm{ha}^{-1}$. However the lower values of seed yield (7141) and straw yield (2591) was recorded in without $\mathrm{Zn}$ application.

Table 1: Seed and Straw yield of soybean as influenced by zinc mobilizing cultures and zinc levels

\begin{tabular}{|c|c|c|}
\hline Treatment & Seed yield $\left(\mathrm{kg} \mathrm{ha}^{-1}\right)$ & Straw yield $\left(\mathrm{kg} \mathrm{ha}^{-1}\right)$ \\
\hline \multicolumn{3}{|l|}{ Zinc solubilizers (S) } \\
\hline S0: Control & 1941 & 2731 \\
\hline S1: Pseudomona striata & 2345 & 2866 \\
\hline S2: Bacillus megaterium & 2001 & 2817 \\
\hline S3: Trichoderma viride & 2041 & 2786 \\
\hline S.Em. \pm & 49.19 & 21.72 \\
\hline C.D. at $5 \%$ & 142.0 & 62.73 \\
\hline \multicolumn{3}{|l|}{ Levels of $\mathrm{ZnSO}_{4}(\mathrm{Zn})$} \\
\hline $\mathrm{Zn0}: \mathrm{ZnSO}_{4} 0 \mathrm{~kg} \mathrm{ha}^{-1}$ & 1741 & 2591 \\
\hline $\mathrm{Zn} 1: \mathrm{ZnSO}_{4} 10 \mathrm{~kg} \mathrm{ha}^{-1}$ & 1967 & 2805 \\
\hline $\mathrm{Zn} 2: \mathrm{ZnSO}_{4} 20 \mathrm{~kg} \mathrm{ha}^{-1}$ & 2195 & 2862 \\
\hline $\mathrm{Zn} 3: \mathrm{ZnSO}_{4} 30 \mathrm{~kg} \mathrm{ha}^{-1}$ & 2426 & 2942 \\
\hline S.Em. \pm & 49.19 & 21.72 \\
\hline C.D. at $5 \%$ & 142.0 & 62.73 \\
\hline \multicolumn{3}{|l|}{ Interaction (SxZn) } \\
\hline S.Em.土 & 98.38 & 43.45 \\
\hline C.D. at $5 \%$ & 284.12 & 125.47 \\
\hline $\mathrm{CV} \%$ & 8.18 & 2.69 \\
\hline
\end{tabular}

Zaidi and Singh (2001) ${ }^{[4]}$ observed that inoculation with Bradyrhizobium Japonicum strains SB-12 and difference isolates of Pseudomona as well as their possible combination significantly increased yield of soybean over control. This might be due to reduction in infection by soil pathogen and greater seedling emergence. Similarly, Goudar et al. (2008) ${ }^{[5]}$ found that grain yield of soybean was significantly influenced by the seed inoculation of Bradyrhizobium japonicum strains along with micronutrients over uninoculated control. Further, Gupta (2006) [6] noted that the seed inoculation with Rhizobium $+P S B+$ Azotobacter increased grain yield in chickpea. Thereafter, Prasad et al. (2017) indicate significant impact of Zn solubilizing microorganisms on dry pod and dry haulm yield of groundnut.

Table 1a: Interaction effect of zinc mobilizing cultures and graded level of zinc on seed yield and straw yield of soybean

\begin{tabular}{|c|c|c|c|c|}
\hline Treatment & $\begin{array}{c}\mathrm{Zn0:} \mathrm{ZnSO}_{4} \\
\text { 0 kg ha-1 }\end{array}$ & $\begin{array}{c}\mathrm{Zn1}: \mathrm{ZnSO}_{4} \\
10 \mathrm{~kg} \mathrm{ha}^{-1}\end{array}$ & $\begin{array}{c}\mathrm{Zn2:} \mathrm{ZnSO}_{4} \\
20 \mathrm{~kg} \mathrm{ha}^{-1} \\
\end{array}$ & 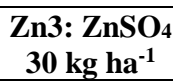 \\
\hline \multicolumn{5}{|c|}{ Seed yield $\left(\mathrm{kg} \mathrm{ha}^{-1}\right)$} \\
\hline S0: Control & 1802 & 1896 & 1996 & 2072 \\
\hline S1: Pseudomona striata & 1730 & 2053 & 2658 & 2940 \\
\hline S2: Bacillus megaterium & 1723 & 1955 & 2046 & 2281 \\
\hline S3: Trichoderma viride & 1709 & 1965 & 2079 & 2410 \\
\hline
\end{tabular}




\begin{tabular}{|c|c|c|c|c|}
\hline Interaction (SxZn) & S & Zn & SXZn & 98.38 \\
\hline SEm+ & 49.19 & 49.19 & 284.12 & \\
\hline CD at 5\% & 142.0 & 142.0 & 2744 & 2857 \\
\hline \multicolumn{5}{|c|}{ Straw yield $\left(\mathbf{k g ~ h a}^{-1}\right)$} \\
\hline S0: Control & 2622 & 2702.70 & 2972 & 3055 \\
\hline S1: Pseudomona striata & 2507 & 2929.00 & 2890 & 2927 \\
\hline S2: Bacillus megaterium & 2647 & 2805.07 & 270 & \\
\hline S3: Trichoderma viride & 2588 & Zn & SXZn & \\
\hline Interaction (SxZn) & S & 21.72 & 43.45 & \\
\hline SEm+ & 21.72 & 62.73 & 125.47 & \\
\hline
\end{tabular}

Significantly highest dry pod yield and dry haulm yield of groundnut was noted in RDF + Rhizobium + Pseudomona striata but treatment RDF + Rhizobium + Pseudomona fluorescens, $\mathrm{RDF}+$ Rhizobium + Trichoderma viride, $\mathrm{RDF}+$ Rhizobium + Trichoderma harzianum and $\mathrm{RDF}+$

Rhizobium + Burkholderia cenocepacia were found statistically at par. Lowest biological yields were obtained in treatment RDF + Rhizobium .

Further, Ekundayo (2003) ${ }^{[7]}$ also observed greater seedlings emergence with inoculated seeds compared with uninoculated, maximum straw yield was recorded with Pseudomona. However, Patel et al. (2010) ${ }^{[10]}$ also noted that application of $20 \mathrm{~kg} \mathrm{~N}+40 \mathrm{~kg}$ P2O5 ha $\mathrm{ha}^{-1}$ and seed inoculation with Rhizobium + PSB increasing seed yield and straw yield in cowpea. Thereafter Pable et al. (2010) [9] reported the significant effect of the sulphur and zinc on yield of soybean in Vertisol and found the highest increase in grain and straw yield of $1755 \mathrm{~kg} \mathrm{ha}^{-1}$ and $3114 \mathrm{~kg} \mathrm{ha}^{-1}$ respectively with the application of $30 \mathrm{~kg} \mathrm{~S} \mathrm{ha}{ }^{-1}+2.5 \mathrm{~kg} \mathrm{Zn} \mathrm{ha}^{-1}+\mathrm{RDF}$ treatment. Similarly, (Bairagi et al., 2007) ${ }^{[10]}$ conducted a field experiment consisted of three levels of zinc $(0,10,20$, $\left.30 \mathrm{~kg} \mathrm{ha}^{-1}\right)$ and four levels of P (0, 50, 75, $\left.10030 \mathrm{~kg} \mathrm{ha}^{-1}\right)$ in Maharashtra during kharif 2004 to study the effect of zinc and phosphours on grain yield and straw yield due to application of zinc. The grain yield was highest with $10 \mathrm{~kg} \mathrm{Zn} \mathrm{ha}^{-1}(15.15$ and $26.75 \mathrm{q} \mathrm{ha}^{-1}$ ).

Effect of zinc mobilizing cultures and zinc levels on enzymativ activities in soil after harvest of soybean

Soil enzymatic activities can display the overall level of soil biological activity as well as transforming course of soil nutrients and are important indices to measure the fertility level of soil

\section{Dehydrogenase activity in soil}

Dehydrogenase is considered as an indicator of overall microbial activity because it occurs intracellularly in all living microbial cells and it is linked with microbial respiratory processes. The dehydrogenase enzyme is known to oxidize soil organic matter by transferring protons and electrons from substrates to acceptors. These processes are part of respiration, pathways of soil microorganisms and closely related to the type of soil. related to dehydrogenase activity in soybean indicate significant effect of zinc solubilizers and graded level of zinc.

The results indicated that dehydrogenase activity in the rhizosphere soil gradually increased ranged betweem (49.50 to $60.33 \mu \mathrm{g}$ TPF $\mathrm{g}^{-1}$ soil $24 \mathrm{hr}^{-1}$ ) showing significantly higher dehydrogenase activity in Pseudomona striata treated plots follows by Bacillus megaterium and Trichoderma viride. Whereas, significantly lower dehydrogenase activity per plot were noted in uninoculated control. Similarly, graded levels of zinc in the form of zinc sulphate also increase the dehydrogenase activity with each incremental dose up to 30 $\mathrm{kg} \mathrm{ZnSO}_{4} \mathrm{~kg} \mathrm{ha}^{-1}$. The dehydrogenase activity as influenced by $\mathrm{Zn}$ application ranged from 48.67 to $59.97 \mathrm{TPF} \mathrm{g}^{-1}$ soil 24 $\mathrm{hr}^{-1}$.

Interaction effect of zinc solubilizers and zinc levels on dehydrogenase activity in Table $2 \mathrm{a}$. Showing significantly the highest dehydrogenase activity was noticed under in Pseudomona striata $\mathrm{X} \mathrm{ZnSO}_{4} 30 \mathrm{~kg} \mathrm{ha}^{-1}\left(67.33 \mathrm{TPF} \mathrm{g}^{-1}\right.$ soil $24 \mathrm{hr}^{-1}$ ) it was found at par with Bacillus megaterium $\mathrm{X}$ $\mathrm{ZnSO}_{4} \quad 30 \mathrm{~kg} \mathrm{ha}^{-1}$. However the lower values of dehydrogenase activity (44 TPF $\mathrm{g}^{-1}$ soil $24 \mathrm{hr}^{-1}$ ) was recorded in uninoculated control.

Table 2: Effect of zinc mobilizing cultures and zinc levels on enzymatic activities in soil after harvest of soybean

\begin{tabular}{|c|c|c|c|c|}
\hline Treatments & $\begin{array}{c}\text { Soil Dehydrogenase } \\
\left(\mu \mathrm{g} \mathrm{g}^{-1} \text { soil }\right)\end{array}$ & $\begin{array}{c}\text { Acid phosphatase } \\
\left(\mu \mathrm{g} \mathrm{g}^{-1} \text { soil }\right)\end{array}$ & $\begin{array}{c}\text { Alkaline phosphatase } \\
\left(\mu \mathrm{g} \mathrm{g}^{-1} \text { soil }\right)\end{array}$ & $\begin{array}{l}\text { Soil Urease } \\
\left(\mu \mathrm{g} \mathrm{g}^{-1} \text { soil }\right)\end{array}$ \\
\hline \multicolumn{5}{|l|}{ Zinc solubilizers (S) } \\
\hline S0: Control & 49.50 & 46.67 & 68.75 & 74.50 \\
\hline S1: Pseudomona striata & 60.33 & 56.58 & 77.67 & 84.50 \\
\hline S2: Bacillus megaterium & 58.38 & 52.66 & 73.83 & 81.08 \\
\hline S3: Trichoderma viride & 50.37 & 49.89 & 70.75 & 76.00 \\
\hline S.Em. \pm & 1.22 & 0.39 & 0.40 & 0.47 \\
\hline C.D. at $5 \%$ & 3.54 & 1.13 & 1.15 & 1.37 \\
\hline \multicolumn{5}{|l|}{ Levels of $\mathrm{ZnSO}_{4}(\mathrm{Zn})$} \\
\hline Zn0: ZnSO4 $0 \mathrm{~kg} \mathrm{ha}^{-1}$ & 48.67 & 47.00 & 67.58 & 73.83 \\
\hline Zn1: ZnSO4 $10 \mathrm{~kg} \mathrm{ha}^{-1}$ & 53.46 & 50.33 & 72.00 & 77.17 \\
\hline Zn2: ZnSO4 $20 \mathrm{~kg} \mathrm{ha}^{-1}$ & 56.48 & 52.77 & 74.75 & 81.17 \\
\hline Zn3: ZnSO4 $30 \mathrm{~kg} \mathrm{ha}^{-1}$ & 59.97 & 55.70 & 76.67 & 83.92 \\
\hline S.Em. \pm & 1.22 & 0.39 & 0.40 & 0.47 \\
\hline sC.D. at $5 \%$ & 3.54 & 1.13 & 1.15 & 1.37 \\
\hline \multicolumn{5}{|l|}{ Interaction (SxZn) } \\
\hline S.Em. \pm & 2.45 & 0.78 & 0.80 & 0.95 \\
\hline C.D. at $5 \%$ & 7.08 & 2.27 & 2.31 & 2.75 \\
\hline $\mathrm{CV} \%$ & 7.77 & 2.65 & 1.91 & 2.09 \\
\hline
\end{tabular}


Dehydrogenase activity reflects the oxidative activity or intensity of metabolism of soil microflora and can be used as an indicator of microbial activity or populations in soil (Beura and Rakshit, 2011) ${ }^{[11]}$. Our results are confirmed with the findings of Kohler et al., (2007) ${ }^{[12]}$; Mader et al., (2010) ${ }^{[13]}$ and Rana et al., (2012) [14] who reported that the higher dehydrogenase activity in the rhizosphere soils with inoculation can be ascribed to the availability of a high quantity of biodegradable substrates and hence an improvement in their microbial activity. Similarly, Ramesh et al., (2014) ${ }^{[15]}$ reported that there is significant increase in dehydrogenase activity with the inoculation of Bacillus aryabhattai strains. Futher, Nihorimbere et al. (2011) ${ }^{[16]}$ who reported more microbial activities increased the dehydrogenase activity in rhizosphere due to more availability of food material for its growth.

Dotaniya et al. (2014) [5] reported the maximum DHA (Dehydrogenase activity) was at 75 DAS. It is might be due to vigorous growth of the crop at 75 DAS and root exudation also more in this period. Nihorimbere et al. (2011) [16] reported more microbial activities and increase in the DHA in rhizosphere due to more availability of food material for its growth. Thereafter, The dehydrogenase activity at flowering $\left(72.89 \mu \mathrm{g} \mathrm{g}^{-1} 24 \mathrm{~h}^{-1}\right)$ and harvest $\left(49.78 \mu \mathrm{g} \mathrm{g}^{-1} 24 \mathrm{~h}^{-1}\right)$ were highest with the treatment receiving combined application of $150 \mathrm{~kg} \mathrm{~N} \mathrm{ha}^{-1}+\mathrm{FYM}+$ Bio fertilizers in rice (Goutami et al., 2015) ${ }^{[18]}$. Further, Apoorva (2016) ${ }^{[19]}$ reported that the highest dehydrogenase activity was observed in the treatment receiving RDF+ Soil application of biozinc @ $30 \mathrm{~kg} \mathrm{ha}^{-1}$ $\left(86.5 \mu \mathrm{g}\right.$ TPF produced $\mathrm{g}$ soil $\mathrm{d}^{-1}$ ) which was on par with RDF+ Soil application of $\mathrm{ZnSO}_{4} @ 25 \mathrm{~kg} \mathrm{ha}^{-1}(81.9 \mu \mathrm{g} \mathrm{TPF}$ produced $\mathrm{g}$ soil $\left.\mathrm{d}^{-1}\right)$. These treatments were followed by RDF+ Soil application of bio zinc @ $15 \mathrm{~kg} \mathrm{ha}^{-1}(76.8 \mu \mathrm{g}$ TPF produced $\mathrm{g}$ soil $\left.\mathrm{d}^{-1}\right)$. The lowest dehydrogenase activity was observed in control $\left(30.2 \mu \mathrm{g}\right.$ TPF produced $\mathrm{g}$ soil d $\left.\mathrm{d}^{-1}\right)$ which was on par with RDF+ foliar application of $0.2 \% \mathrm{ZnSO}_{4}$ spray $\left(39.2 \mu \mathrm{g}\right.$ TPF produced g soil $\left.\mathrm{d}^{-1}\right)$.

\section{Acid phosphatase activity in soils}

The activities of acid phosphatase is predominate in acid soil and predominantly due to plants. Phosphatase activity has been closely correlates with $\mathrm{pH}$. However, acid phosphatase is mostly of plant and associated fungal origin. The acid phosphatase activity would be more dependent upon the nutritional status of the plant. The acid phosphatase activity was significantly influenced by different zinc solubilizing microbial strains and data is presented in Table 2. Zinc solubilizers influenced the acid phosphatase activity which

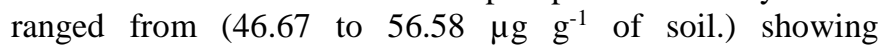
significantly higher acid phosphatase activity in Pseudomona striata treated plots follows by Bacillus megaterium and Trichoderma viride. Whereas, significantly lower acid phosphatase activity per plot were noted in uninoculated control. Similarly, applied levels of zinc in the form of zinc sulphate also increase the acid phosphatase activity with each incremental dose up to $30 \mathrm{~kg} \mathrm{ZnSO}_{4} \mathrm{~kg} \mathrm{ha}^{-1}$. The acid phosphatase activity as influenced by $\mathrm{Zn}$ application ranged from 47.00 to $55.70 \mu \mathrm{g} \mathrm{g}^{-1}$ of soil.

Interaction effect of zinc mobilizing cultures and zinc levels on dehydrogenase activity in table $2 \mathrm{a}$. Showing significantly the highest acid phosphatase activity was noticed under in Pseudomona striata $\mathrm{X} \mathrm{ZnSO}_{4} 30 \mathrm{~kg} \mathrm{ha}^{-1}\left(59.67 \mu \mathrm{g} \mathrm{g}^{-1}\right.$ of soil) it was found at par with Bacillus megaterium $\mathrm{X} \mathrm{ZnSO}_{4} 30 \mathrm{~kg}$ $\mathrm{ha}^{-1}$. However the lower values of acid phosphatase $\left(42 \mu \mathrm{g} \mathrm{g}^{-1}\right.$ of soil) was recorded in without $\mathrm{Zn}$ application.
Our results are also concurrent with the findings of Rama Lakshmi et al., (2014). However, the majority of the acid phosphatase is mostly of plant and associated fungal origin. Whereas, the alkaline phosphatase is more likely to be of microbial origin. The acid phosphatase activity would be more dependent upon the nutritional status of the plant (Naseby et al., 2000) ${ }^{[20]}$. Further, the results emerged out indicated that the soil alkaline phosphatase and acid phosphatase enzyme activity was improved with RDF + Bacillus megaterium after harvest of soybean Kumar and

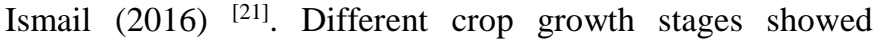
different amount of acid phosphatase activity, it might be due to secretion of root exudates and biochemical changes in plant system (Dotaniya et al., 2014) ${ }^{[17]}$. Similarly, Our results are also concurrent with the findings on the acid phosphatase activity revealed that there was no significant difference among different zinc solubilizing bacterial isolates, however, it was recorded in the range of 43.73 to $52.39 \mu \mathrm{g}$ of PNP released g soil hr-1 Vidyashree (2015) ${ }^{\text {[22] }}$. Further, Srilatha et al. (2013) ${ }^{[23]}$ observed that soil enzyme activities increased with increasing rate of NPK application. Acid phosphatase ranged from 64.3 to $90.3,77.3$ to $127.9,67.6$ to121.3 and 48.8 to 78.1 during kharif and 72.7 to $120.6,169.8$ to $206.1,86.1$ to 138.7 and 65.6 to $100.5 \mu \mathrm{g}$ of $\mathrm{p}$-nitrophenol released $\mathrm{g}^{-1}$ soil $\mathrm{h}^{-1}$ at 30, 60, 90 DAT and harvest respectively during rabi. Similarly, Apoorva (2016) ${ }^{[19]}$ reported that the highest acid phosphatase activity was observed in the treatment receiving RDF+ Soil application of biozinc@30 kg ha ${ }^{-1}(135.2 \mu \mathrm{g}$ of $p$ nitrophenol $\mathrm{g}^{-1}$ soil $\mathrm{hr}^{-1}$ ) which was on par with RDF+ Soil application of ZnSO4 @ $25 \mathrm{~kg} \mathrm{ha}^{-1}$ (129.8 $\mu \mathrm{g}$ of $p$-nitrophenol $\mathrm{g}^{-1}$ soil $\left.\mathrm{hr}^{-1}\right)$. The lowest acid phosphatase activity was observed in control $\left(72.3 \mu \mathrm{g}\right.$ of $p$-nitrophenol $\mathrm{g}^{-1}$ soil $\left.\mathrm{hr}^{-1}\right)$ which was on par with RDF+ foliar application of $0.2 \%$ $\mathrm{ZnSO}_{4}$ spray $\left(72.3 \mu \mathrm{g}\right.$ of $p$-nitrophenol $\mathrm{g}^{-1}$ soil $\mathrm{hr}^{-1}$.

\section{Alkaline phosphatase activity in soils}

The data pertaining to alkaline phosphatase enzyme activity is narrated in Table 2 . Which was significantly affected due to the inoculation of different $\mathrm{ZnS}$ microbial cultures. Zinc solubilizers influenced the alkaline phosphatase activity which ranged from (68.75 to $77.67 \mu \mathrm{g} \mathrm{g}^{-1}$ of soil.) showing significantly higher acid phosphatase activity in Pseudomona striata treated plots follows by Bacillus megaterium and Trichoderma viride. Whereas, significantly lower acid phosphatase activity per plot were noted in control plots. Similarly, graded levels of zinc in the form of zinc sulphate also increase the alkaline phosphatase activity with each incremental dose up to $30 \mathrm{~kg} \mathrm{ZnSO}_{4} \mathrm{~kg} \mathrm{ha}^{-1}$. The acid phosphatase activity as influenced by $\mathrm{Zn}$ application ranged from $67.58(\mathrm{Zn} 0)$ to $76.67 \mu \mathrm{g} \mathrm{g}^{-1}$ of soil $\left(\mathrm{ZnSO}_{4}\right) 30 \mathrm{~kg} \mathrm{ha}^{-1}$. Interaction effect of zinc solubilizers and zinc levels on alkaline phosphatase activity in Table 2a. Increase the alkaline phosphatase activity significantly synergistic effect of each factor was recorded on each other showing significantly the highest alkaline phosphatase activity was noticed under in Pseudomona striata $\mathrm{X} \mathrm{ZnSO}_{4} 30 \mathrm{~kg} \mathrm{ha}^{-1}\left(82.33 \mu \mathrm{g} \mathrm{g}^{-1}\right.$ of soil) it was found at par with Bacillus megaterium and Trichoderma viride $\mathrm{X} \mathrm{ZnSO}_{4} 30 \mathrm{~kg} \mathrm{ha}^{-1}$. However the lower values of alkaline phosphatase $\left(66.33 \mu \mathrm{g} \mathrm{g}^{-1}\right.$ of soil) was recorded in without $\mathrm{Zn}$.

The activities of both acid and alkaline phosphatases were significantly improved over control levels in the rhizosphere upon inoculation. This might be due to increased microbial and root activities as previously reported by Kaleeswari, (2007) Futher Kumar and Ismail (2016) observed that alkaline 
phosphatase activity was noted significantly highest in treatment RDF + Rhizobium + Bacillus megaterium over rest of treatments. It was closely at par with RDF + Rhizobium + Pseudomona fluorescens. Whereas, acid phosphatase activity was also noted maximum in RDF + Bacillus megaterium. But it was found at par with the treatment RDF + Pseudomona fluorescens, RDF + Pseudomona striata and RDF + Trichoderma viride. Similarly, Badda et al., (2013) who observed the highest increment in alkaline phosphatase activity in the plants inoculated with A. laevis $+T$. viride $+P$. fluorescens. Further, Vidyashree (2015) ${ }^{[22]}$ observed that Maximum alkaline phosphatase activity was observed in the treatment inoculated with $B$. aryabhattai $(68.9 \mu \mathrm{g}$ of PNP released/g soil/hour) which is significantly different from other treatments. Least activity of alkaline phosphatase was found in uninoculated control (47.6 $\mu \mathrm{g}$ of PNP released/g soil/hour). Similarly Srilatha et al. (2013) ${ }^{[23]}$ observed that soil enzyme activities increased with increasing rate of NPK application. Alkaline phosphatase activity ranged from 73.5 to $94.8,81.8$ to $135.2,70.2$ to $125.9,52.8$ to 92.6 in kharif and
81.7 to $126.1,127.9$ to $177.4,85.6$ to 151.4 and 69.1 to 109.4 $\mu \mathrm{g}$ of p-nitrophenol released $\mathrm{g}^{-1}$ soil $^{-1}$ at 30, 60, 90 DAT and harvest respectively in rabi. Thereafter, Apoorva (2016) ${ }^{[19]}$ reported that the highest alkaline phosphatase activity was observed in the treatment receiving $\mathrm{RDF}+$ Soil application of biozinc @ $30 \mathrm{~kg} \mathrm{ha}^{-1}(206.1 \mu \mathrm{g}$ of $p$-nitrophenol g-1 soil hr-1) which was on par with RDF+ Soil application of $\mathrm{ZnSO}_{4} @ 25$ $\mathrm{kg} \mathrm{ha}^{-1}\left(190.0 \mu \mathrm{g}\right.$ of $p$-nitrophenol $\mathrm{g}^{-1}$ soil $\left.\mathrm{hr}^{-1}\right), \mathrm{RDF}+$ Soil application of bio zinc@15 kg ha-1 $(187.4 \mu \mathrm{g}$ of $p$-nitrophenol $\mathrm{g}^{-1}$ soil hr$\left.{ }^{-1}\right), \mathrm{RDF}+$ Soil application of nano zinc @ $15 \mathrm{~kg} \mathrm{ha}^{-1}$ $\left(176.0 \mu \mathrm{g}\right.$ of $p$-nitrophenol $\mathrm{g}^{-1}$ soil $\left.\mathrm{hr}^{-1}\right)$. The lowest acid phosphatase activity was observed in control $(87.0 \mu \mathrm{g}$ of $p$ nitrophenol $\mathrm{g}^{-1}$ soil $\mathrm{hr}^{-1}$ ) which was on par with $\mathrm{RDF}+$ foliar application of $0.2 \% \mathrm{ZnSO}_{4}$ spray $\left(90.0 \mu \mathrm{g}\right.$ of $p$-nitrophenol $\mathrm{g}^{-1}$ soil $\left.\mathrm{hr}^{-1}\right)$. Thereafter, Prasad and Ismail (2016) ${ }^{[24]}$ showed that the enzymatic activity in soil after harvest of groundnut crop was influenced by different $\mathrm{ZnS}$ microbial inoculants. Activity of alkaline phosphatase was noted significantly highest in treatment $\mathrm{RDF}+$ Rhizobium + Bacillus megaterium $\left(76.38 \mu \mathrm{g} \mathrm{g}^{-1}\right)$.

Table 2a: Interaction effect of zinc solubilizers and graded level of zinc on enzymatic activity in soil

\begin{tabular}{|c|c|c|c|c|}
\hline Treatments & Zn0: $\mathrm{ZnSO}_{4} 0 \mathrm{~kg} \mathrm{ha}^{-1}$ & Zn1: $\mathrm{ZnSO}_{4} 10 \mathrm{~kg} \mathrm{ha}^{-1}$ & Zn2: $\mathrm{ZnSO}_{4} 20 \mathrm{~kg} \mathrm{ha}^{-1}$ & Zn3: $\mathrm{ZnSO}_{4} 30 \mathrm{~kg} \mathrm{ha}^{-1}$ \\
\hline \multicolumn{5}{|c|}{ Soil dehydrogenase $\left(\mu \mathrm{g} \mathrm{g}^{-1}\right.$ soil $)$} \\
\hline S0: Control & 44.00 & 47.67 & 51.33 & 55.00 \\
\hline S1: Pseudomonas striata & 50.67 & 58.00 & 65.33 & 67.33 \\
\hline S2: Bacillus megaterium & 50.67 & 54.84 & 62.00 & 66.00 \\
\hline S3: Trichoderma viride & 49.33 & 53.33 & 47.27 & 51.56 \\
\hline Interaction & $\mathrm{S}$ & $\mathrm{Zn}$ & SXZn & \\
\hline SEm+ & 1.22 & 1.22 & 2.45 & \\
\hline $\mathrm{CD}$ at $5 \%$ & 3.54 & 3.54 & 7.08 & \\
\hline \multicolumn{5}{|c|}{ Acid phosphatase ( $\mu \mathrm{g} \mathrm{g}^{-1}$ soil) } \\
\hline S0: Control & 42.00 & 44.00 & 48.00 & 52.67 \\
\hline S1: Pseudomona striata & 51.00 & 57.00 & 58.67 & 59.67 \\
\hline S2: Bacillus megaterium & 48.67 & 51.33 & 53.33 & 57.30 \\
\hline S3: Trichoderma viride & 46.33 & 49.00 & 51.08 & 53.16 \\
\hline Interaction & $\mathrm{S}$ & $\mathrm{Zn}$ & SXZn & \\
\hline SEm+ & 0.39 & 0.39 & 0.78 & \\
\hline $\mathrm{CD}$ at $5 \%$ & 1.13 & 1.13 & 2.27 & \\
\hline \multicolumn{5}{|c|}{ Alkaline phosphatase ( $\mu \mathrm{g} \mathrm{g}^{-1}$ soil) } \\
\hline S0: Control & 66.33 & 68.00 & 69.33 & 71.33 \\
\hline S1: Pseudomona striata & 70.00 & 77.67 & 80.67 & 82.33 \\
\hline S2: Bacillus megaterium & 68.00 & 72.00 & 76.67 & 78.67 \\
\hline S3: Trichoderma viride & 66.00 & 70.33 & 72.33 & 74.33 \\
\hline Interaction & $\mathrm{S}$ & $\mathrm{Zn}$ & SXZn & \\
\hline $\mathrm{SEm}+$ & 0.40 & 0.40 & 0.80 & \\
\hline $\mathrm{CD}$ at $5 \%$ & 1.15 & 1.15 & 2.31 & \\
\hline \multicolumn{5}{|c|}{ Urease ( $\mu \mathrm{g} \mathrm{g}^{-1}$ soil) } \\
\hline S0: Control & 69.33 & 72.67 & 76.33 & 79.67 \\
\hline S1: Pseudomona striata & 79.00 & 82.67 & 86.33 & 90.00 \\
\hline S2: Bacillus megaterium & 74.33 & 78.33 & 84.00 & 87.67 \\
\hline S3: Trichoderma viride & 72.67 & 75.00 & 78.00 & 78.33 \\
\hline Interaction & $\mathrm{S}$ & $\mathrm{Zn}$ & SXZn & \\
\hline SEm+ & 0.47 & 0.47 & 0.95 & \\
\hline $\mathrm{CD}$ at $5 \%$ & 1.37 & 1.37 & 2.75 & \\
\hline
\end{tabular}

\section{Urease activity in soils}

The data clearly demonstrates a remarkable urease activity increased by the application of zinc solubilizing microbial inoculants compated to without application of inoculants. The data presented in Table 2. Shows zinc solubilizers influenced the urease activity which ranged from (74.50 to $84.50 \mu \mathrm{g} \mathrm{g}^{-1}$ of soil.) showing significantly higher urease activity in Pseudomona striata treated plots follows by Bacillus megaterium and Trichoderma viride. Whereas, significantly lower urease activity per plot noted in uninoculated control.
Similarly, graded levels of zinc in the form of zinc sulphate also increase the urease activity with each incremental dose of zinc up to $30 \mathrm{~kg} \mathrm{ZnSO}_{4} \mathrm{~kg} \mathrm{ha}^{-1}$. The urease activity as influenced by $\mathrm{Zn}$ application ranged between $73.83(\mathrm{Zn} 0)$ to $83.92 \mu \mathrm{g} \mathrm{g}^{-1}$ of soil $\left(\mathrm{ZnSO}_{4}\right) 30 \mathrm{~kg} \mathrm{ha}^{-1}$.

Interaction effect of zinc solubilizers in to zinc levels in Table $2 \mathrm{a}$. Increase the urease activity significantly synergistic effect of each factor was recorded. Showing significantly the highest urease activity was noticed under in Pseudomona striata $\mathrm{X}$ $\mathrm{ZnSO}_{4} 30 \mathrm{~kg} \mathrm{ha}^{-1}\left(90.00 \mu \mathrm{g} \mathrm{g}^{-1}\right.$ of soil) it was found at par 
with Bacillus megaterium in to $\left(\mathrm{ZnSO}_{4} 30 \mathrm{~kg} \mathrm{ha}^{-1}\right)$. However the lower values of urease $\left(69.33 \mu \mathrm{g} \mathrm{g}^{-1}\right.$ of soil) was recorded in $\mathrm{Zn} 0 \mathrm{X}$ S0 uninoculated control.

Rai and Yadav (2011) ${ }^{[25]}$ reported that Application of RDF + FYM @ 10 tonnes ha ${ }^{-1}$ recorded significantly highest urease activity (45.15 and $47.90 \mathrm{mg} \mathrm{NH}_{4} \mathrm{~N} \mathrm{~kg} / 24 \mathrm{hr}$ ) than any other treatments. Similarly, slight increase in the urease activity was observed at 70 DAS of sorghum as compared to 40 DAS, may be due to solubilization of complex organic compounds at steady rate. The increase in urease activity under RDF and $\mathrm{RDF}+\mathrm{FYM}$ as compared to other treatments may be due to higher root biomass as a result of vigorous growth, thereby increasing urease activity in these treatments. The increased microbial population under organics and INM was responsible for increase in urease activity of the soil; this can be ascribed to the organic manure which acts as a source of carbon and energy for heterotrophs and provides sufficient nutrition for the proliferation of microbes and their activities in terms of soil enzymes. Thereafter, Vidyashree (2016) ${ }^{\text {[22] }}$ reported that significantly higher urease activity $(24.80 \mu \mathrm{g}$ NH4-N/g soil/hour) was recorded in B. aryabhattai inoculated treatment which was followed by Bacillus sp. (PAN-TM1) (21.40 $\mu \mathrm{g} \mathrm{NH4-N/g} \mathrm{soil/hour).}$

\section{Conclusion}

From the study, it can be concluded that, the incremental levels of zinc solublizers and $\mathrm{ZnSO} 4$ caused significant results show that, inoculation of Pseudomona striata, Bacillus megaterium and Trichoderma viride also increases yield and enzymatic activity. Similarly, graded levels of zinc in the form of zinc sulphate also increased with each incremental dose up to $30 \mathrm{~kg} \mathrm{ZnSO} 4 \mathrm{~kg} \mathrm{ha}^{-1}$.

\section{References}

1. Anonymous. Area, Production and productivity of soybean in India kharif (monsoon) 2016-17, 2017. www.oer/crop.po.doc.

2. Usha Mina, Anita Chaudhary, Anju Kamra. Effect of $B t$ Cotton on enzymes activity and microorganisms in rhizosphere, Division of Nematology, Indian Agricultural Research Institute, New Delhi-110012, J of Agr Science, 2011, 3(1).

3. Sarathambal C, Thangaraju M. Assessing the zinc solubilization ability of Gluconacetobacter diazotrophicus in maize rhizosphere using labelled (65) Zn compounds. Indian J Microbiol. 2010; 50:103-9.

4. Zaidi SFA, Singh HP. Effect of dual inoculation of fluorescent Pseudomona and Bradyrhizobium japonicum on nutrient uptake plant growth, nodulation and yield of soybean (Glycine max (L) Merr.) Appl. Biol. Res. 2001; $3: 1-8$.

5. Goudar G, Mudenoor MG, Savalgi VP. Effect of micronutrient supplemented Bradyrhizobium biofertilizers on nodulation, dry matter production and yield of soybean (Glycine max L.) Merril.). Leg. Res. 2008; 31(1):20-25.

6. Gupta SC. Effect of combined inoculation on nodulation, nutrient uptake and yield of chickpea in Vertisol. J Indian Soc. Soil Sci. 2006; 54(2):251-254.

7. Ekundayo EO. Effect of common pesticides used in the niger delta basin of southern Nigeria on soil microbial populations. Env. Monit Assess. 2003; 89(1):35-41.

8. Patel MM, Patel IC, Patel BS, Acharya S, Tikka SBS. Effect of biofertilizers at different fertility levels on growth and yield of cowpea (Vigna ungiliculata (L.)
Walp) under rainfed conditions. J Arid Legumes. 2010; 7(2):140-143.

9. Pable KV, Bari MS, Rahamn MG, Islam MJ, Hoque ATMR. Effect of zinc, boron sulphur, magnesium on the growth yield of potato. Pak. J Biological Sci. 2010; 4(9):1090-1093.

10. Bairagi BN, Mahulikar DN, Hiwarale JS. Effect of Zn and $\mathrm{P}$ on yield, oil and protein content of soybean. J Soil Crops. 2007; 17:292-293.

11. Beura K, Rakshit A. Effect of $B t$ cotton on nutrient dynamics under varied soil Italian J Agron. 2011; 6:3540.

12. Kohler J, Caravaca F, Carrasco L, Roldan A. Interactions between plant growth-promoting rhizobacterium, an AM fungus and a phosphate-solubilising fungus in the rhizosphere of Lactucasativa. Appl. Soil Ecol. 2007; 35:480-487.

13. Mader P, Kiser F, Adholeya A, Singh R, Uppal HS. Inoculation of root microorganisms for sustainable wheat-rice and wheat-blackgramrotations in India. Soil Biol. Biochem. 2010; 43:609-619.

14. Rana A, Joshi M, Prasanna R, Shivay YS, Nain L. Biofortification of wheat through inoculation of plant growth promoting rhizobacteria and cyanobacteria. Eur. J Soil Biol. 2012; 50:118-126.

15. Ramesh A, Sharma SK, Sharma MP, Yadav N, Joshi OP. Inoculation of zinc solubilizing Bacillus aryabhattai strains for improved growth, mobilization and biofortification of zinc in soybean and wheat cultivated in Vertisols of Central India. Appl. Soil Ecol. 2014; 73:8796.

16. Nihorimbere V, Ongena M, Smargiaji M. Beneficial effect of rhizosphere microbial community for plant growth and health. Biotechnol. Agron S.C. Environ. 2011; 5(2):327-337.

17. Dotaniya ML, Kushwah SK, Rajendra S. Rhizosphere effect of kharif crops on phosphatase and dehydrogenase activities in Typic Halpluster. Natl. Acad. Sci. Lett. 2014; 37(2):103-106.

18. Goutami N, Rani PP, Pathy RL, Babu PR. Soil properties and biological growth, yield and quality of soybean (Glycine max L.). Prog. Agril. res. 2015; 55:468-470.

19. Apoorva MR. Effect of sources and methods of application of zinc on growth, yield and nutrient uptake in rice (Oryza sativa L.) MSc thesis Professor Jayashankar Telangana State Agricultural University Rajendranagar, Hyderabad, 2016.

20. Naseby DC, Pascual JA, Lynch JM. Effect of biocontrol strains of Trichoderma on plant growth, Pythiumultimum populations, soil microbial communities and soil enzyme activities. J Appl. Microbiol. 2000; 88:161-169.

21. Kumar B, Ismail Syed, Pawar Anuradha. Influence of Different Microbial Inoculants On Biological Health of soil and economics in soybean crop grown on Vertisol Progressive Research - An International Journal. 2016; 11:2012-2015

22. Vidyashree DN. Evaluation of zinc solubilizing bacterial strain on zinc uptake of tomato, Msc Thesis submitted to the University of Agricultural Science, Bengaluru, 2015.

23. Srilatha M, Rao PC, Sharma SHK, Bhanu Rekha K. Influence of long term fertilizer application on soil phosphatase enzyme activity and nutrient availability in rice-rice cropping system. J of Rice Research. 2013; 2:45-54. 
24. Sable Prasad, Ismail Syed, Sonwane NS. Effect of zinc solubilizing microorganisms on yield and economics of groundnut grown on Vertisol. Int J of Tro. Agri. 2016a; 35(3):831-833.

25. Rai TN, Yadav J. Influence of inorganic and organic nutrient sources on soil enzyme activities. Journal of the Indian Society of Soil Science. 2011; 59(1):54-56. 